Volume 4 Issue 1, March 2019: pp. 1-10. Copyright @ LamLaj. Faculty of Law, Lambung Mangkurat University, Banjarmasin, South Kalimantan, Indonesia. ISSN: 2502-3136 | e-ISSN: 2502-3128.

Open Access at: http://lamlaj.ulm.ac.id/web/

\title{
THE VALUE OF LOCAL WISDOM IN THE CONTEXTUALIZATION OF BUDGETING IN ACEH
}

\section{Delfi Suganda ${ }^{1}$, Teguh Murtazam²}

Ar-Raniry State Islamic University

Jl. Syekh Abdu Rauf, Kopelma Darussalam Banda Aceh, 23111

Fax: 62-651-7557321+Email: delfi_suganda@yahoo.com

Muamalah Islamic Economics Research Center Aceh

Jl.Tandi, Lr Pesantren, No.01, Ateuk Jawo, Baiturrahman District, Banda Aceh

Fax:085361907245+Email: tmurtazam16@gmail.com

Submitted : 01/11/2018 Reviewed 07/02/2019 Accepted:29/03/2019

\begin{abstract}
Aceh Province is a special area. Acts No. 11 of 2006 concerning the Government of Aceh provides freedom in terms of managing the government, especially regarding the implementation of Islamic law in Aceh. Islamic Shari'a is not only understood as a rule that regulates education, but also about regulation in government management in Aceh. One part of the government is about compiling regional spending in Aceh. This research is focused on budgeting which will be contextualized with Acehnese values, namely the local value of implementing Islamic law in Aceh. Priority indicators for a budget arrangement so that they fulfill the requirements as ideal budgets according to Islam (Islamic budget ideal). In terms of substance, this research is classified into qualitative research, which focuses on the depth and sharpness of the study. So if more quantitative research is on a broad, broad framework, the qualitative study is digging, swooping, and deep. Islamic budgeting is a value that in this context wants to be included in the budget in South Aceh. Based on the results of the study it was found that in terms of the determination of post-expenditure it is possible to include the values of Islamic Shari'a. In this case the post expenditure is based on maqasid as-Syari'iyah. In terms of revenue, only zakat, shadaqah, and infaq are possible to be contextualized. As for 'usyr, rikaz, etc., it is not possible because regional revenues from the fiscal side are regulated so rigid in state regulations
\end{abstract}

Keywords: Contextualization; Islamic Budgeting; Budget

\section{INTRODUCTION}

Budget is crucial in a country, progress and the withdrawal of a country has strong relevance to budget policies that are applied because the process of running a country is financed by a budget formulated jointly by the 
parties concerned. ${ }^{1}$ The process of budgeting in a country that adheres to a democratic system is influenced by a variety of interconnected factors, such as legal, political, social and cultural aspects and the ideology adopted by the parties involved in the process of drafting it.

Variables that influence the preparation of the budget often make the drafting process full of debate. Even more than that, the debate has made the country become "hostage" because the time used to unite the vision of the parties in the drafting process is so long that the budget born from a process like this is threatened to become a budget that does not meet the needs of the people because it is rushed and past the specified time. As a result, the budget only seems symbolic and is an object of fraud.

Various cases of conflict in budget discussions are seen in various parts of the world. The United States as one of the world's democratic model countries, recorded in the last quarter century has experienced twice the government shutdown ${ }^{2}$ due to budget

1 In Indonesia and several democratic countries in the world, such as the United States. The budget is a joint product between the executive and legislative institutions.

2 Dalam dunia keuangan terminology ini didefinisikan sebagai "The closure of nonessential offices of the government due to lack of approval on the government programs budget for the upcoming fiscal year. Approval is reached if Congress passes all of the spending bills regarding the federal budget. If an agreement is not achieved, a government shutdown will close many federally run operations, and halt work for federal employees unless they are considered essential. Some organizations still stay open by running on cash reserves, but once these run out, if a solution is not found, they will also close. The shutdown stays in effect until a compromise is reached and a budget bill is passed. " Lebih lanjut dapat dilihat pada : (http://www.investopedia.com/terms/g/ conflicts, namely during the Bill Clinton administration and the last in President Barack Obama's 2013 due to congressional rejection of the proposed ceiling of debt by President Obama for the insurance of all citizens as part of a health policy called Obamacare. ${ }^{3}$

Examples of other budget conflicts also occur in Indonesia, conflicts in the 2016 budgeting took place in seven provinces in Indonesia, namely Aceh, DKI Jakarta, West Papua, Riau Islands, Papua, Central Kalimantan, and North Sumatra. The cause of the majority of these delays is the different perceptions between the executive and the legislature in the discussion and formulation. ${ }^{4}$ Another thing that is also caused by interest subjectivity and the construction of understanding of different parties produces budget products that are potentially not in accordance with what is expected by the community and causes the use of the budget to be ineffective in the multisectoral development process. So what happens is the slowdown in the development of various aspects that want to be realized.

On the other hand Islam as a religion which is rahmatan lil 'alamin, not only regulates the issue of human relations with God (hablum minallah), but also includes various aspects of human life in a holistic manner so that it is known as comprehensive way of life because it has an integrated sys-

government-shutdown.asp\#ixzz416F1MphN) accessed on February $24^{\text {th }}, 2016$, at 22.35 WIB

3 Further see (http://bisnis.liputan6.com/ $\mathrm{read} / 709902 / \mathrm{kronologi-detik-detik-tutupnya-}$ pemerintah-amerika-serikat) accessed on February $24^{\text {th }}, 2015$, at 22.12 WIB.

4 Further see (http://news.detik.com/berita/3104452/ selain-dki-ada-7-provinsi-lainnya-yang-terancamtelat-sahkan-apbd-2016), accessed on February $24^{\text {th }}, 2016$, at $23: 17$ p.m. WIB. 
tem $^{5}$ which makes tauhid as the equilibrium point $^{6}$, including the rules on how the government (ulil amri) should prepare a budget that is in accordance with the divine rules set out in the Al-Qur'an and the Sunnah of the Prophet Muhammad and it is an obligation for Muslims to try to implement it maximally in many aspects of life ${ }^{7}$. In addition, in a broader perspective. Study of alternative ways to solve social problems both related to problems between individuals and individuals, as well as problems in the context of the country. It is normal to do so by switching to studies that come from certain theological teachings. This includes the teachings of Islam. So that studying Islam to find solutions for the existing problems is not something that is considered taboo anymore because it is due to the tendency of the development of knowledge to have led in that direction.

Aceh as the only area legalized by law to implement Islamic law in a comprehensive manner, ${ }^{8}$ within the framework of the unitary state of the Republic of Indonesia, should adopt Islamic Sharia values in all aspects, including in the budgeting process, so that it is not impressed that Shari'a Islam is only a matter of criminal law and worship only. But more than that, Islamic Shari'a must also be tried to enter into various other dimensions, one of which is budgeting so that later the budget born from the legislative and executive products in Aceh is a budget product that contains the values of Islamic Shari'a, thus it

5 See Q.S al-Maidah : 3.

6 See Q.S adz-Dzariat : 56

7 See Q.S Thaha : 123, an-Nazia'at : 40-41, alAn'am : 153, al-Baqarah : 137, an-Nisa : 115, alAhzab : 36, etc.

8 See Article 20 of the Aceh government law, which mandates the implementation of governance in Aceh must be based on the principle of Islam. is expected that the budget conflict, budget ineffectiveness and budget inefficiencies can be minimized, even eliminated.

Culturally the explanation above is very possible, because there is a unified vision from the historical-cultural side in the Acehnese struggle for many years. Aceh in the context of its struggle has a vision to carry out Islamic Sharia completely in all people's lives. This vision is embedded and possessed by every Acehnese community that will unite and reduce the various sectoral political interests that exist and are seen so far in the process of budget formulation that causes conflict and makes the budget that is prepared is not on target. With the condition that there is a platfont which is a joint reference in formulating a budget that can be claimed academically that the standard is a standard that is truly extracted from the noble values of Islam.

There fore, the study of the contextualization of Islamic budgeting principles in budgeting in Aceh (state studies in the preparation and design of APBK in South Aceh District) is very important. This study expect that the parties involved in the process of budgeting have an ideal model that comes from a unified vision that is to be applied, namely Islam that can unite all interests while being an accelerator of the development process because the essence of Islam is identical to progress so that Islam run kaffah, it will stimulate progress and accelerate it. ${ }^{9}$

The facts about the existence of regulations or legal instruments in Aceh both from national and local legal instruments make the researcher do a research by using the term "contextualization" so that the existing Islamic budgeting concept can be adjusted to that fact. The result woul be a budget that is not

9 See Q.S al-'Araf : 96 
only in accordance with the Islamic budgeting concept but also in accordance with the existing laws.

Islamic Shari'a is applicable to all aspects of human life, as the way of life, there is not a single part of human life that escapes the universal values of Islam. Included in the life of the state. The state system and its governance are generally explained in religious texts $(\mathrm{Nu}-$ sus as-Syari'yah) to aspects of state resource use (management budgeting). The application of the general principles of Islam in managing budget policies is part of the system process of a country, as well as part of the application of scientific development, especially in the study of religion, culture, politics, state administration, and the humanities.

This process is because the existing values and systems cannot answer the needs of the community in relation to budgeting. Many social problems which then cannot be resolved with budget policies are managed based on the current value system. other than that in a country that has value unification (pooling of values) or value consensus (value agreement) then there must be a unifier which becomes an ideal indicator that can measure a policy whether or not can be classified as a good policy.

Islam as a religion and living system which is believed by many people in various countries can be a unifier in the mission to seek such standardization. Even for countries such as Indonesia and Aceh in particular, these Islamic values unite all the interests that exist in the political process of drafting a budget which is a media to deliver political interests.

The general values of Islam that exist in religious texts must be translated and contextualized with the discussion discourse.
This study of Islamic badgeting will begin by contextualizing universal values into a whole theory which will later be referred to as the Islamic budgeting theory.

The theoretical basis used is the maslahah theory as the purpose of observation. The indicators described in this study as the state expenditure budget posts aim to achieve the greatest benefit which is part of the purpose of observation. So, if the budget posts later represent maslahah, the budget management is considered to have fulfilled the Sharia aspects. Furthermore, after the process of constructing or formulating the theory, the researcher then adjusts to the legal norms in Aceh which, according to initial observations, are very cooperative to apply this Islamic model.

This study seeks to answer and provide solutions to some of the problems described above and summarized in the following formulation of the problem.

1. What are the priority indicators that must be met in a budget drafting so that the budget meets the requirements to be called as an ideal budget according to Islam (the ideal Islamic budget)?

2. How is the prototype of a budget in accordance with the concept of Islamic budgeting in the context of Aceh and its existence as part of the Unitary State of the Republic of Indonesia?

\section{RESEARCH METHODS}

In terms of substance, this research is classified into qualitative research, which focuses on the depth and sharpness of the study. So, if it is a quantitative research it will be broader in the framework, however the qualitative study is more comperhensive and deep ${ }^{10}$. In terms of data collection method, this research

10 Cristine Daymon dan Immy Holloway. 2008. Metode Riset Kualititif dalam Publik Relation dan 
is classified into the library research, because it relies on studies in the existing literature. Besides, as a reinforcement and complementary study, interviews with authority holders will be conducted. So that the process of contextualization which is also part of the main objective of this study can be achieved.

The analytical method used in this study is an explanatory methodology. i.e. researchers link or search for causation between two or more concepts (variables) to be examined. Researchers need concept definitions, conceptual frameworks and theoretical frameworks. Researchers need to carry out activities theorizing to produce initial guesses (hypotheses) between variables one with other variables. Variables are measurable concepts. This theorizing activity is in a theoretical framework. So that is also referred to as the type of correlational research. ${ }^{11}$ While the data used is secondary data taken and processed from several references.

This research was focused on the South Aceh Regency area. South Aceh Regency is the oldest district on the south west coast of Aceh. This district has been divided into several regency expansion regions, namely Aceh Singkil, Aceh Barat Daya, Subussalam Municipality. But in reality when compared to the pemekaran district, South Aceh is far behind, and even more economically left behind compared to Southwest Aceh.

\section{ANALYSIS AND DISCUSSION}

This study, from scientific systematization perspective, can be classified into the study of a group of economic political scienc-

Marketing Comunication. Jogjakarta: Bentang, hlm. 8

11 Rahmat Kriyantono, 2006. Teknik Praktis Riset Komunkasi, Jakarta: Kencana, hlm. 58 es because it discusses policy (decision) and decision making (decision making) ${ }^{12}$ with theoretical-practical nature.

The theoretical implication is being used in this research because there is an effort to construct a new theory about Islamic budgeting by considering several aspects such as the concept of maslahah mursalah, and maqasid al-Shari'ah. Until today, related research has not been found at all, at least within the scope of the Ar-Raniry Islamic University, Aceh, and Indonesia. Including observations that the author did by using search engine facilities such as Google, Amazon, and Yahoo. Using the keyword Islamic budget, Islamic budget theory, and Islamic budgeting. So, it can be said that this study is completely new. Similar studies but not specific as the researchers examined, found several studies such as collectively written research and recorded with the title Budged Theory in the Public Sector which discusses budgeting from various perspectives, both from the perspective of own economics, as well as scientific interconnection, such as a combination of the theory of nomenclature and political economy written by Thomas $\mathrm{P}$ LeLoup entitled The Sparation of Power Principle and Budged Decision Making which discusses the theory of separation of power and decision making in budgeting, another study which is still in the same book is the study that trying to explain factual axioms related to existing budgeting theories, titled Budged Theory for New Century written by Lance P LeLoup. As well as there are several other writings that discuss budgeting theory from various perspectives in this book.

This research is based on some of the main theories as the basis of the construction

12 Budiardjo, M. 2003. Dasar-dasar Ilmu politik. Jakarta: Gramedia Pustaka Utama, hlm. 9 
of a new theory of construction that later will be called as Islamic budgeting theory. Like the theory of Maslahah, and the interpretation of the letter of Joseph. The study of al-Maslahah is a treasure that has been developed by Muslim academics such as al-Ghazali, ${ }^{13}$ Izzuddin Abd Salam, ${ }^{14}$ and so on. So academically this theory has a strong scientific roots and is a general theory that is widely disseminated into various contemporary Islamic studies. Included in the budget policy review, but in this discourse there is no specific study that is so far from this side that it is considered new.

Yet there are some studies that are considered to represent (though not too specific) about public finance in Islamic classical times such as al-kharraj. There are several books of al-kharraj that have been known as the book written by Muawiyah bin Ubaidillah, but the book written by Muawiyah bin Ubaidillah has not been found until today. Only the books of al-kharraj written by Abu Yusuf, Yahya bin Adam, and Qudamah bin Ja'far.

The book of al-Kharraj Abu Yusuf was written with a figh approach and highly contextualized with the time and place of the writing of the book. It is reasonable to bear in mind the purpose of writing this book initially is to fulfill the request of the Caliphate to have a book of fiscal implementation based on the values of the Islity. So it is not surprising that in this book many are found ijtihad and advice ${ }^{15}$.

13 Abu Hamid Muhammad Al-Ghazali. 1997. Musytasyfa min 'Ilmi al-Usul, ahqiq wa Ta'liq Muhammad Sulaiman Al-Asyqar. Beirut: Muasasaat Ar-Risalah, 1417 H / 1997 M, 1st Juz, p. 416-417

14 Izzuddin Abd Salam, Qawaid al-Ahkam fil Masalih al-Anam. Cairo: Maktabah al-Kulliyyah al-Azhariyyah, 1994, 1st Juz, p. 5

15 Abu Yusuf, 1979. Kitab al-Kharaj. Beirut: Dar alMa'rifah, p.3
The al-kharraj book written by Qudamah bin Jafar contains criticisms on tax collectors and taxis that the tax system implemented by the government is incompatible with the Islamic Sharia so Qudamah bin Jafar answers it with this book, because at that time the position of Qudamah bin Jafar is government ulema who have recognized his position in government. 16 While the al-karraj book written by Yahya bin Adam from the content side is not much different from what Abu Yusuf wrote. But his approach to writing is different, Abu Yusuf is more on the side of the juridical analysis as Yahya bin Adam compiles the hadiths related to the issues discussed. ${ }^{17}$

The next classic reference which is considered as the representation of Islamic public finance studies is the book al-Amwal. Kitab al-Amwal which until now is the book al-Amwal written by Abu Ubayd, Abu Humaid ibn Zanjawaih and Abu Ja'far ibn Nashr al-Dawudi. ${ }^{18}$

Somewhat different from the previous book al-Ahkam As-Sultaniyah discussed the same issue but more specifically in the discussion of public finance, topics of administration, macroeconomics, monetary, and so on. Written by two scholars in the mid-15th century, namely Abu al-Hasan al-Mawardi, and

16 Ahamed Kameel and Nazmul Ahsan, TT. "AlKharaj and Related Issues," TT: TP, p. 206

17 Ahamed Kameel Mydin Meera and Syed Nazmul Ahsan, "Al-Kharaj and Related Issues: A Comparative Study of Early Islamic Scholarly Thoughts and Their Reception by Western Economists," in Abulhasan M. Sadeq and Aidit Ghazali (ed.), Readings in Islamic Economic Thought (Kuala Lumpur: Longman Malaysia, 1992), p. 205.

18 According to Sabahuddin Azmi, there are at least six books written under the title Al-amwal. See the book, Islamic Economics, p. 32. 
Abu Ya'la al-Fara. The study spectrum of the two books is relatively the same. And in the same period.

The following table briefly describes some classical literature that discusses public policy in general which touches on the budgeting aspect.

Table 1

Description of the Classical Literature of Islamic Public Policy

\begin{tabular}{|c|c|c|c|c|}
\hline Title & Compiler & Background & Style & Content \\
\hline \multirow{3}{*}{$\frac{\sqrt{\pi}}{\frac{\pi}{2}}$} & Abu Yusuf & $\begin{array}{l}\text { Meet the } \\
\text { request of the } \\
\text { Caliph, Harun } \\
\text { al-Rasyid (w. } \\
809 \text { ). }\end{array}$ & $\begin{array}{l}\text { Judicial- } \\
\text { oriented Very } \\
\text { pragmatic } \\
\text { with fiqh-style }\end{array}$ & $\begin{array}{l}\text { More on putting forward fatwas } \\
\text { or advice on leadership behavior }\end{array}$ \\
\hline & $\begin{array}{l}\text { Yahya ibn } \\
\text { Adam }\end{array}$ & $\begin{array}{l}\text { General } \\
\text { guidelines for } \\
\text { the basics of } \\
\text { Islamic public } \\
\text { finance }\end{array}$ & $\begin{array}{l}\text { Compilation- } \\
\text { oriented }\end{array}$ & $\begin{array}{l}\text { More on putting forward the } \\
\text { hadiths about public finance }\end{array}$ \\
\hline & $\begin{array}{l}\text { Quda mah } \\
\text { ibn Ja'far }\end{array}$ & $\begin{array}{l}\text { Counter to } \\
\text { criticism of the } \\
\text { katib (collectors } \\
\text { and tax } \\
\text { administrators) }\end{array}$ & $\begin{array}{l}\text { J u d i c i a } 1- \\
\text { o r i e n t e d } \\
\text { Descriptive }\end{array}$ & $\begin{array}{l}\text { Expressing various opinions of } \\
\text { scholars on public finance }\end{array}$ \\
\hline \multirow{3}{*}{ 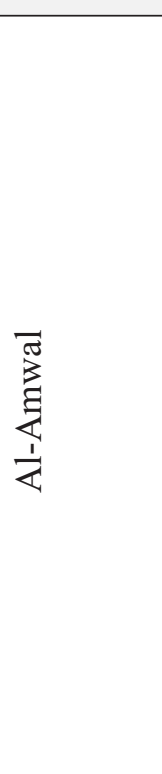 } & Abu Ubaid & $\begin{array}{l}\text { Reflections on } \\
\text { a scholar as } \\
\text { well as a legal } \\
\text { practitioner } \\
\text { (qadi) }\end{array}$ & $\begin{array}{l}\text { Normative } \\
\text { history } \\
\text { Legal } \\
\text { reasoning }\end{array}$ & $\begin{array}{l}\text { systematic and comprehensive } \\
\text { book on public finance }\end{array}$ \\
\hline & $\begin{array}{l}\text { Abu } \\
\text { Humaid ibn } \\
\text { Zanjawaih }\end{array}$ & $\begin{array}{l}\text { Syarah book on } \\
\text { the book of al- } \\
\text { amwāl by Abu } \\
\text { Ubayd }\end{array}$ & $\begin{array}{l}\text { Normative } \\
L \text { e } g \text { a } 1 \\
\text { reasoning }\end{array}$ & $\begin{array}{l}\text { Islamic leadership norms; } \\
\text { Islamic public finance }\end{array}$ \\
\hline & $\begin{array}{l}\text { Abu Ja }{ }^{\text {eefar }} \\
\text { ibn Nashr al- } \\
\text { Dawudi. }\end{array}$ & $\begin{array}{l}\text { Lifting taxation } \\
\text { practices that } \\
\text { were in effect at } \\
\text { that time }\end{array}$ & $\begin{array}{l}\text { E m p irical } \\
\mathrm{L} \text { e } \mathrm{g} \text { a } 1 \\
\text { reasoning }\end{array}$ & $\begin{array}{l}\text { Public finance from the } \\
\text { perspective of the Māliki school }\end{array}$ \\
\hline
\end{tabular}




\begin{tabular}{|c|c|c|c|c|}
\hline 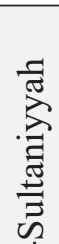 & $\begin{array}{l}\text { Abu al- } \\
\text { Hasan al- } \\
\text { Mawardi (w. } \\
\text { 1058) }\end{array}$ & $\begin{array}{l}\text { General } \\
\text { guidelines for } \\
\text { the basics of } \\
\text { Islamic public }\end{array}$ & $\begin{array}{l}\text { Legal } \\
\text { reasoning } \\
\text { (Comparative } \\
\text { mazhab) }\end{array}$ & $\begin{array}{l}\text { Public finance; tax, land } \\
\text { management; public spending } \\
\text { etc. Government and } \\
\text { administrative procedures }\end{array}$ \\
\hline 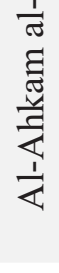 & $\begin{array}{l}\text { Abu Ya'la } \\
\text { al-Farra' (w. } \\
\text { 1065). }\end{array}$ & $\begin{array}{l}\text { General } \\
\text { guidelines for } \\
\text { the basics of } \\
\text { Islamic public } \\
\text { finance }\end{array}$ & $\begin{array}{l}\text { Legal } \\
\text { reasoning } \\
\text { (Hanbaliah) }\end{array}$ & $\begin{array}{l}\text { Public finance; tax, land } \\
\text { management; public spending } \\
\text { etc. Government and } \\
\text { administrative procedures }\end{array}$ \\
\hline
\end{tabular}

Islam views the budgeting from two aspects. The first aspect is the responsibility of the government that must be fulfilled to society. Both Muslims also view budgeting as the responsibility of the government to God Subhanahu wa ta'ala. Rasulullah Shalallahu 'alaihi wa salam said:

"Each of you is a leader and every leader will be asked for responsibility for what he leads (H.R Bukhari, No. 844)"

Therefore, the study of budgeting in Islam other than the object of mainstream science study as mentioned above also touches the aspect of tauhid or aqidah, beside that budgeting in Islam is directly related to fiqh siyasah, economic doctrinal aspect that is fiqh muamalah and economic empirical aspect iqtisadiyah.

The purpose of budgeting in Islamic economics can be divided into two categories. The first category is the short-term goal of creating maqasid syariah, while the second is to create happiness in the world and in the hereafter (falah oriented). So the budget polarization follows the two main goals.

From the side of Islam acceptance has several posts such as zakat, waqf, shadaqah, infaq, and special taxes. As for the expenditure side of Islam, it only specifies specifically on the post of income derived from zakat only called asnaf (the recipients of zakat) while others are divided by grouping from the abstract reduction process of maqasid syariah concept of keeping property, life, religion, heredity, and intellect. So budgeting provisions to support and boost development in the category are already detailed in the budgeting structure.

In the Law Legal System theory ${ }^{19}$ developed by Lawrence M. Friedmen there are 3 elements that must be developed to form a good legal system. As well as relevant as an indicator to assess the feasibility of applying the concept of Islamic Budgeting into the South Aceh budgeting process. The analysis is based on the following indicators.

\section{Legal Structure}

In a policy as law. There should be an institution that becomes an authorization to plan, implement, evaluate and supervise these programs. Therefore, Friedmen includes this element as an important element in forming a good legal system. Without this element, the theory or policy substance will become para-

19 This theory was originally a legal theory in the field of state administration which discussed the good legal structure so that law enforcement could run as desired. This theory is then the loan researcher to test whether Islamic budgeting can work in South Aceh or not, due to the budgeting process in Indonesia, specifically in southern Aceh exactly where the process of compiling the product is planned. 
lyzed and cannot be implemented properly. Friedman defines the legal structure as follows:

"To begin with, the legal system has the structure of a legal system consist of elements of this kind: the number and size of courts; their jurisdiction...Structure also means how the legislature is organized ... what procedures the police department follow, and so on. Structure, in way, is a kind of cross section of the legal system... a kind of still photograph, with freezes the action" 20

South Aceh as other regions in Indonesia, In formulating a budget involving several authorities. First is the executive in this case carried out by several key institutions such as the Finance Office, Development Agency and Regional Planning. In the context of the application of Islamic budgeting there is one institution that can be directly involved in the process of drafting the APBK, specifically the PPAS (Priority Temporary Budget Platform), namely the Islamic Sharia service. The Islamic Shari'a Office as BAPEDDA can map anything that needs to be prioritized and ended from anything that has been formulated by other authorities such as BAPEDDA then clarified in six types of interests as explained in the theory of maqasid as-Syari'iyyah. ${ }^{21}$ If later there are those who have not fulfilled the six groups, the Islamic Sharia service can add and complete it.

Based on the results of normative observation and analysis. Such a model can be applied in South Aceh, given the existence of

20 Lawrence M. Friedman. 1984. TJ. TT: TP, p. 5-6

21 The concept of 5 maqasid syar'iyyah developed by Imam As-Syathibi added one concept developed by Yusuf Qardhawi namely hifdhul bi'ah (protecting the environment) the Islamic Sharia Service Agency for a long time and it is time to maximize its authority as given in the Law on Aceh Governance. In addition, the development of Aceh in general must be based on Islamic values.

\section{Legal Substance}

Legal substance or legal substance is the material of the law itself.

Friedmen defines:

"Another aspect of the legal system is its substance. By this is meant the actual rules, norm, and behavioral patterns of people inside the system ...the stress here is on living law, not just rules in law books".

In the Indonesian legal system legal materials are laws and the like. The substance also includes living law, not only the rules in the law (law books). As a country that still adheres to the civil law system or continental system (although some legislation has also embraced the Common Law System or Anglo Saxon) it is said that law is written regulations while unwritten regulations are not declared as law. This system affects the legal system in Indonesia. One influence is the existence of the principle of legality in the Criminal Code. In Article 1 of the Criminal Code it is determined "there is no criminal act that can be legalized if there are no rules governing it". So that whether or not an action is subject to legal sanctions if the act has obtained its arrangement in the laws and regulations.

The process of budgeting at all levels of government in Indonesia is governed by a set of laws and regulations. So if there are certain values that want to be included, of course it must be tested first whether these values can be accommodated by regulations in Indonesia.

Islamic budgeting is a value that in this 
context wants to be included in the budget in South Aceh. Based on the results of the analysis it was found that in terms of postexpenditure determination it is possible to include the values of Islamic Shari'a. In this case the post expenditure is based on maqasid as-Syari'iyah.

In terms of revenue, only zakat, shadaqah, and infaq are possible to be contextualized. As for 'usyr, rikaz, etc. It is not possible because regional revenues from the fiscal side are regulated so rigid in state regulations. ${ }^{22}$ Simply put as follows:

\begin{tabular}{c|c|c}
\hline Post & Possible & Not Possible \\
\hline Income & & $\mathrm{V}$ \\
\hline Expenditure & $\mathrm{V}$ & \\
\hline
\end{tabular}

To contextualize values in Islamic budgeting can actually be started when the National Medium-Term Development Plan (RPJM) is compiled, but it is rather difficult to intervene because the central (national) political pressure is beyond the control of the South Aceh district government. So, to overcome this, it can be done when compiling the South Aceh RPJMD. Specifics can be intervened when the South Aceh District Government prepares the PPA (Priority and budget platform). Its essence in terms of expenditure is the application or contextualization of Islamic Budgeting Theory might be done.

\section{Legal Culture}

Friedmen's definition of legal culture is:

"The third component of legal system, of legal culture. By this we mean people's attitudes

22 Some regulations related to managing regional finance, namely Acts No. 25 of 2004, Acts No. 17 of 2003, Acts No. 1 of 2004, Acts No. 15 of 2004, Acts No. 33 of 2004, Acts No. 32 of 2004, PP No. 58 of 2005, PP No. 38 of 2007, PP No. 41 of 2007 , Permendagri No. 13 of 2006, Permendagri No. 59 of 2007, Acts No. 11 of 2006. toward law and legal system their belief ...in other word, is the culminate of social thought and social force which determines how law is used, avoided, or abused".

In the context of the budget, or public financial policy. Opportunities for contextualization also need to be measured based on the legal culture that develops in the local area. The authors mean by culture in this study are the people, including the political forces in the area.

After conducting interviews with three representatives of community elements in southern Aceh, it was found that in South Aceh basically agreed with the implementation of Islamic budgeting in budgeting in the area. However, there are a number of things that concern local elements such as the availability of regulations that form the basis of budgeting, and knowledge of policy makers. In terms of public acceptance, it can be seen that the people of South Aceh generally accept that the budget is based on Islamic values.

\section{CONCLUSION}

Budgeting in Islam from the source side is divided into two, namely mandatory income and vouluntary income. As for expenditures, Islamic budgeting bases its post on expenditures based on the five objectives of Shari'a which are made with maqasid as-Syar'iyyah. So, that the five things guaranteed by the Sharia are also guaranteed by the state with all its capabilities, through the budget mechanism. Five things that become the priority of the budget are all activities related to maintaining religion, soul, wealth, relatives and mind. So that if budgeting for this model is carried out then the five things are well maintained and guaranteed by the government. South Aceh 
has a great opportunity to implement an Islamic budgeting system. This result was analyzed by the law legal system theory, Lawrence $M$ Friedman, by looking at three indicators, namely the subtance (material / regulation), structure (representative institution or body) and culture (culture including political conditions in South Aceh)

\section{BIBLIOGRAPHY}

Al-Ghazali, Abu Hamid Muhammad. 1997. Musytasyfa min 'Ilmi al-Usul, ahqiq wa Ta'liq Muhammad Sulaiman Al-Asyqar. Beirut: Muasasaat Ar-Risalah, 1417 H / 1997 M, 1st Juz

Anonim. Government Shutdown. http://www. investopedia.com/terms/g/government shutdown.asp\#ixzz416FlMphN)

Anonymous. Government Shutdown. http:// www.investopedia.com/terms/g/government shutdown.asp \# ixzz416FlMphN) Anonymous. The Chronology of the Times of the Close of the United States Government. http://bisnis.liputan6.com/ read/709902/chronologi-detik-detik-tutupnya-pemerintah-serikat)

Anonymous. Besides DKI, There Are 7 Other Provinces Threatened Late To Endorse APBD. http://news.detik.com/ berita/3104452/selain-dki-ada-7-provinsi-lainnya-yang-terancam-telat-sahkanapbd-16-2016)

Budiardjo, M, 2003. Dasar-dasar Ilmu Politik. Jakarta: Gramedia Pustaka Utama

Daymon, Cristine dan Immy Holloway. 2008. Metode Riset Kualititif dalam Publik Relation dan Marketing Comunication. Jogjakarta: Bentang

Kriyantoro, Rahmat. 2006. Teknik Praktis Riset Komunkas. Jakarta: Kencana

Meera, Ahamed Kameel Mydin and Syed
Nazmul Ahsan. 1992. "Al-Kharaj and Related Issues: Comparative Study of the Thoughts of Early Islamic Scholars and Their Acceptance by Western Economists, " in Abulhasan M. Sadeq and Aidit Ghazali (ed.). Readings in Islamic Economic Thought. Kuala Lumpur: Longman Malaysia S v

Salam, Izzuddin Abd, 1994. Qawaid al-Ahkam fil Masalih al-Anam. Cairo: Maktabah al-Kulliyyah al-Azhariyyah, 1994, 1 st Juz

Yusuf, Abu. 1979. Kitab al-Kharaj. Beirut: Dar al-Ma'rifah

\section{Legislation}

Acts Number 25 of 2004 concerning the National Development Planning System

Acts Number 17 of 2003 concerning State Finance

Acts Number 1 of 2004 concerning State Treasury

Acts Number 15 of 2004 concerning Management Inspections and Financial Responsibilities of Country

Acts Number 33 of 2004 concerning Balancing between the Central Government and Regional Governments

Acts Number 11 Year 2006 concerning Aceh Government

Government Regulation Number 58 of 2005 concerning Regional Financial Management

Government Regulation Number 38 of 2007 concerning Division of Government Affairs between the Government, Provincial Governments and Regency / City Governments

Government Regulation Number 41 of 2007 concerning Regional Charity Organizations Republic of Indonesia 
Minister of Home Affairs Regulation Number 13 Year 2006 concerning Regional Management Guidelines Republic of Indonesia

Minister of Home Affairs Regulation Number 59 Year 2007 concerning Amendment to Minister of Home Affairs Regulation Number 13 Year 2006 concerning Guidelines for Regional Financial Management 